Meiklejohn, J. (1953). J. gen. Microbiol. 8, 58-65.

\title{
Iron and the Nitrifying Bacteria
}

\author{
BY JANE MEIKLEJOHN \\ Soil Microbiology Department, Rothamsted Experimental \\ Station, Harpenden, Hertfordshire
}

\begin{abstract}
SUMMARY: The oxidation of ammonia to nitrite in enrichment cultures of Nitrosomonas spp. was hastened by $6 \mathrm{mg}$. Fe/l. in the medium. Manganese did not replace iron as a stimulant; it was toxic. $N$. europaea (Jensen's strain) and a strain of Nitrobacter winogradskyi had, in pure culture, very small absolute requirements for iron; they oxidized ammonia and nitrite respectively in media purified with 8hydroxyquinoline, and with no iron added. Small amounts of iron hastened the oxidation of ammonia and nitrite; the minimum concentration giving this stimulating effect was $0.1 \mathrm{mg}$. Fe/l. for the strain of Nitrosomonas europaea and $0.3 \mathrm{mg}$. $\mathrm{Fe} / \mathrm{l}$. for the strain of Nitrobacter winogradskyi. The optimum amount of iron for oxidation appeared to be about $6 \mathrm{mg}$./l. for both species. Both species tolerated $112 \mathrm{mg}$. Fe/l. $($ c. $0.002 \mathrm{M})$, but oxidation was delayed, markedly in the case of $N$. winogradskyi, by $560 \mathrm{mg} . / \mathrm{l} .($ (c. $0.01 \mathrm{M})$.
\end{abstract}

Shortly after Winogradsky first isolated species of bacteria which oxidized, respectively, ammonia to nitrite, and nitrite to nitrate, he reported more rapid oxidation when ferrous sulphate was added to the culture media(Winogradsky \& Omeliansky, 1899). Since then iron in some form of combination, and in various amounts, has been added to media used for growing nitrifying bacteria, but the optimum amount of iron and the minimum necessary for growth, have not been determined. It is very difficult to measure the amount of growth of nitrifying bacteria because the cells adhere to solids, including the particles of carbonate in the usual liquid medium; but their activity can be measured by the formation of nitrite from ammonia, or by the disappearance of nitrite as it is oxidized to nitrate. Lees \& Meiklejohn (1948) reported that $6 \mathrm{mg}$. iron/l. increased the rate of nitrite formation in enrichment cultures of Nitrosomonas spp.

\section{METHODS}

Cultures. Preliminary experiments were done with enrichment cultures, from which a strain of $N$. europaea was subsequently isolated (Meiklejohn, 1950). The ammonia-oxidizing bacterium used in pure culture was a strain of $N$. europaea isolated in Denmark by Dr H. L. Jensen (Jensen, 1950). Pure cultures of a strain of Nitrobacter winogradskyi, a nitrite-oxidizing bacterium, were obtained from soil from the Forestry Commission Tree Nursery at Ampthill, Bedfordshire, by two successive platings on nitrite agar. This strain has oval cells, $0 \cdot 8-1 \cdot 0 \times 1 \cdot 0-1 \cdot 2 \mu$. and is non-motile. It forms zoogloeal growth round the chalk particles in liquid medium; cells from a 9-day culture were Gram-negative.

Cultures were grown in the dark at $25^{\circ}$, in $750 \mathrm{ml}$. flasks containing $100 \mathrm{ml}$. portions of medium and closed by beakers. The flasks were rinsed with 
chromic-sulphuric acid cleaning mixture and with water, and autoclaved with distilled water in them, before use.

Media. Enrichment cultures were grown in a liquid medium containing: $\left(\mathrm{NH}_{4}\right)_{2} \mathrm{SO}_{4}, 0.005 \mathrm{M} ; \mathrm{NaCl}, 0.005 \mathrm{M} ; \mathrm{KH}_{2} \mathrm{PO}_{4}, 0.001 \mathrm{M} ; \mathrm{MgSO}_{4}, 0.001 \mathrm{M}$; made up in glass-distilled water, and with $10 \mathrm{~g} . \mathrm{CaCO}_{3} / \mathrm{l}$. added.

For work with pure cultures similar media were used, but were freed as far as possible from heavy metals. Solution $\mathrm{A}$ contained: $\mathrm{NaCl}, \mathbf{0} \cdot \mathbf{6}$ g.; either $\left(\mathrm{NH}_{4}\right)_{2} \mathrm{SO}_{4}, 1.32 \mathrm{~g}$. (for Nitrosomonas sp.) or $\mathrm{NaNO}_{2}, 1 \cdot 0$ g. (for Nitrobacter sp.); glass-distilled water, $180 \mathrm{ml}$; $\mathrm{KH}_{2} \mathrm{PO}_{4}, 0 \cdot 1 \mathrm{M}$ solution (previously boiled) $20 \mathrm{ml}$. The whole solution A was purified with 8-hydroxyquinoline (Waring \& Werkman, $1942 a$ ). Solution B: $\mathrm{MgSO}_{4} \cdot 7 \mathrm{H}_{2} \mathrm{O}, 0 \cdot 14 \mathrm{~g}$.; distilled water $50 \mathrm{ml}$. The complete medium contained: solution A, $100 \mathrm{ml}$.; solution $\mathrm{B}, 50 \mathrm{ml}$.; glassdistilled water, $850 \mathrm{ml}$.; $\mathrm{CaCO}_{3}, 10 \mathrm{~g}$., and was sterilized by autoclaving at $15 \mathrm{lb}$. for $15 \mathrm{~min}$.

Iron was added as ferrous sulphate; amounts of $6 \mathrm{mg}$. $\mathrm{Fe} / \mathrm{l}$. and less were autoclaved in the medium, the iron being added as the required volume of a solution containing $0 \cdot 249 \mathrm{~g}$. $\mathrm{FeSO}_{4} \cdot 7 \mathrm{H}_{2} \mathrm{O} / 100 \mathrm{ml}$. to the culture flasks. For adding larger amounts of iron a solution containing $2 \cdot 78 \mathrm{~g}$. $\mathrm{FeSO}_{4} \cdot 7 \mathrm{H}_{2} \mathrm{O} / 100 \mathrm{ml}$. distilled water was sterilized by filtration through a Ford SB pad, and added to the culture flasks as required after they had been autoclaved.

Manganese (chloride) or copper (sulphate) were added as required to the medium before autoclaving.

Inoculations were made with sterile pipettes; the same volume of liquid culture (0.1-1.0 ml. for different experiments) was added to every flask in the same experiment, in a random order.

Nitrite was estimated colorimetrically with Griess-Ilosvay reagent (Lees \& Quastel, 1946).

\section{RESULTS}

\section{Enrichment cultures}

The effects of various metal supplements on the oxidation of ammonia to nitrite by enrichment cultures containing Nitrosomonas sp. are shown in Fig. 1. The addition of $6 \mathrm{mg} . \mathrm{Fe} / \mathrm{l} .(c .0 .0001 \mathrm{M})$ stimulated the production of nitrite. Manganese did not replace iron as a stimulant, and indeed $1.08 \mathrm{mg}$. $\mathrm{Mn} / \mathrm{l}$. appeared to be poisonous. The effect of manganese was partly counteracted by copper, and almost entirely counteracted by iron; rather more stimulation was given by all three metals together than by iron alone (cf. Lees \& Meiklejohn, 1948).

\section{Nitrosomonas europaea}

The results of a typical experiment with pure cultures of $N$. europaea (Jensen's strain) are shown in Fig. 2. The accumulation of nitrite, formed by the oxidation of ammonia, was measured in this case. The first point of interest is that nitrite was formed, though slowly, in the control cultures without added iron, although the medium had been purified with 8 -hydroxyquinoline 
A substantial proportion of the ammonia supplied (about $130 \mathrm{mg}$.) was converted to nitrite in these control cultures.

Secondly, as in the Nitrosomonas enrichment cultures, there was a very marked stimulation of nitrite production by $6 \mathrm{mg}$. Fe/l. in the pure cultures of this (Jensen's) strain of $N$. europaea.

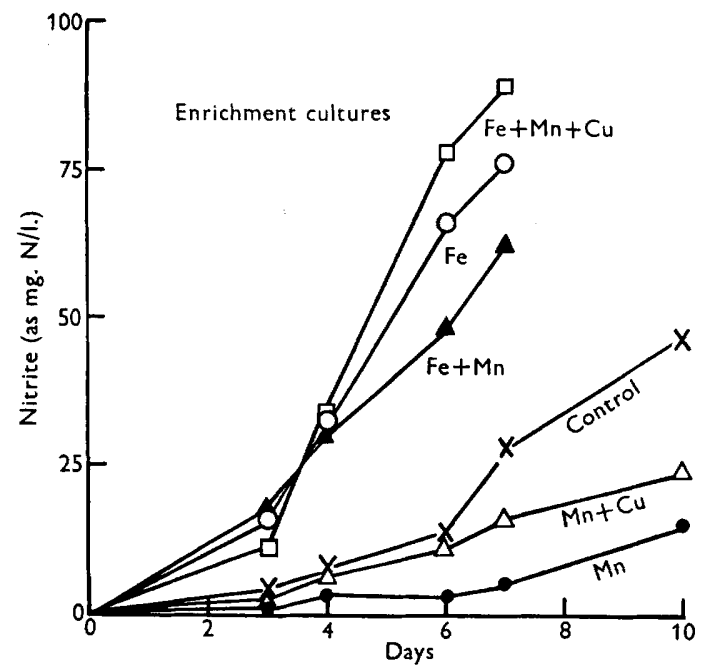

Fig. 1. Nitrite produced from ammonia by enrichment cultures containing Nitrosomonas spp. Metals: $\times-\times$, control (none added); $\bigcirc-O$, iron, $6 \mathrm{mg} . / 1 . ;-0$, manganese, $1.08 \mathrm{mg} . / 1 . ; \Delta-\Lambda$, iron + manganese; $\triangle-\triangle$, manganese + copper, $0.14 \mathrm{mg} . / \mathrm{l}$; $\square-\square$, iron, manganese, and copper.

The results of adding smaller amounts of iron (down to $0.05 \mathrm{mg}$. Fe/1.) are illustrated in Fig. 3. It will be seen that the addition of $0.05 \mathrm{mg}$. Fe/l. had a negligible effect; definite stimulation was given by $0.1 \mathrm{mg}$. $\mathrm{Fe} / \mathrm{l}$., and the stimulation increased with increasing iron concentration up to $6 \mathrm{mg}$. $\mathrm{Fe} / \mathrm{l}$.

Fig. 3 also emphasizes that the effect of iron operated in the early stages of the oxidation (cf. Fig. 2).

Larger amounts of iron were next used with results shown in Fig. 4; 28, 56 and $112 \mathrm{mg}$. Fe/l. all stimulated nitrite production, but no more than was obtained with $6 \mathrm{mg}$. Fe/l. With $560 \mathrm{mg}$. Fe/l. (c. 0.01 M); which gave a heavy brown precipitate in the medium, there was slightly retarded nitrite production as compared with the control.

\section{Nitrobacter winogradskyi}

The activity of $N$, winogradskyi cultures was measured by the rate at which nitrite disappeared from the medium. This disappearance was due to oxidation to nitrate; a strongly positive reaction for nitrate was found in every culture at the end of the experiments.

Fig. 5 shows the results of a typical experiment, which are similar to those obtained with the strains of Nitrosomonas sp. Oxidation (of nitrite) was completed even in the purified medium with no added iron; $6 \mathrm{mg}$. $\mathrm{Fe} / \mathrm{l}$. accelerated the oxidation of nitrite to nitrate. 


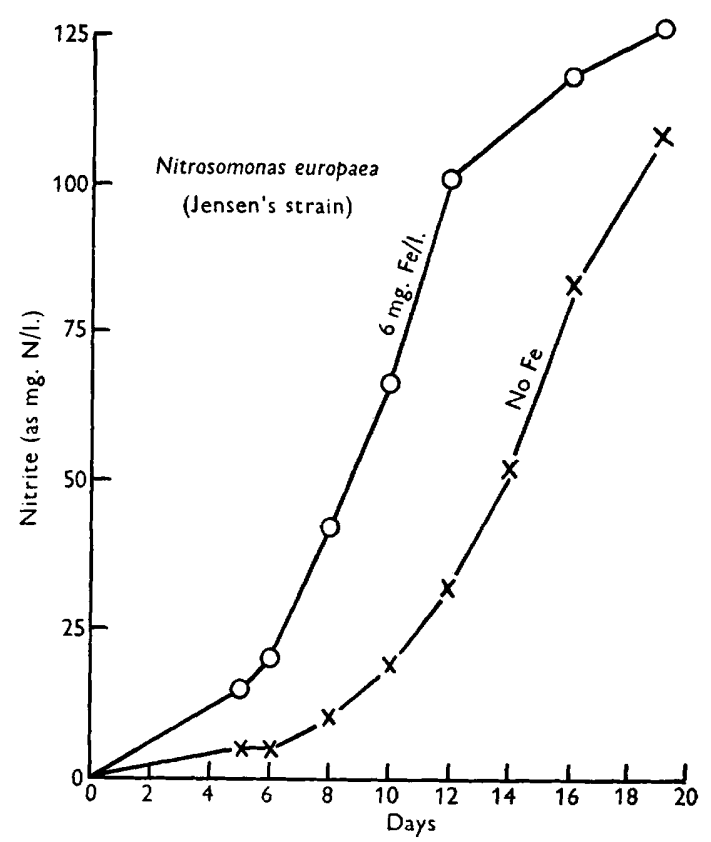

Fig. 2. Nitrite produced from ammonia by a strain of Nitrosomonas europaea. $\times-\times$, control (no added $\mathrm{Fe}$ ); $\mathrm{O}-\mathrm{O}, 6 \mathrm{mg}$. Fe/l. added. (Average values from duplicate cultures.)

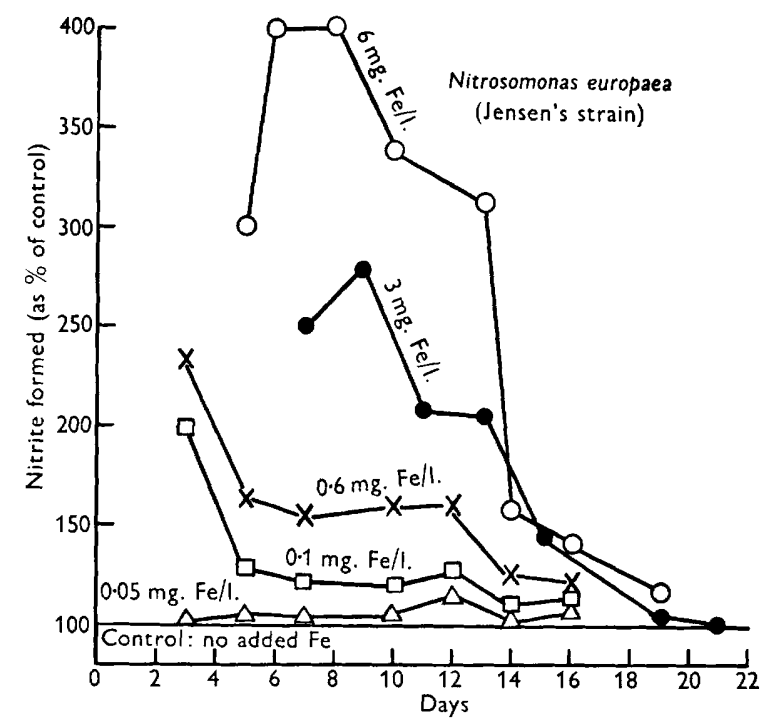

Fig. 3. Effect of different concentrations of Fe on the oxidation of ammonia to nitrite by a strain of Nitrosomonas europaea. The nitrite formed is given as percentages of the amount of nitrite in the control at the corresponding time. $N$. europaea, iron added: $\triangle-\triangle, 0.05 \mathrm{mg} . / \mathrm{l}$; $\square-\square, 0.1 \mathrm{mg} . / \mathrm{l}$; $\times-\times, 0.6 \mathrm{mg} . / 1$; $-0 \mathrm{3.0} \mathrm{mg} . / \mathrm{l}$; $\mathrm{O}-\mathrm{O}, 6.0 \mathrm{mg} . / \mathrm{l}$. (av. of duplicates). 


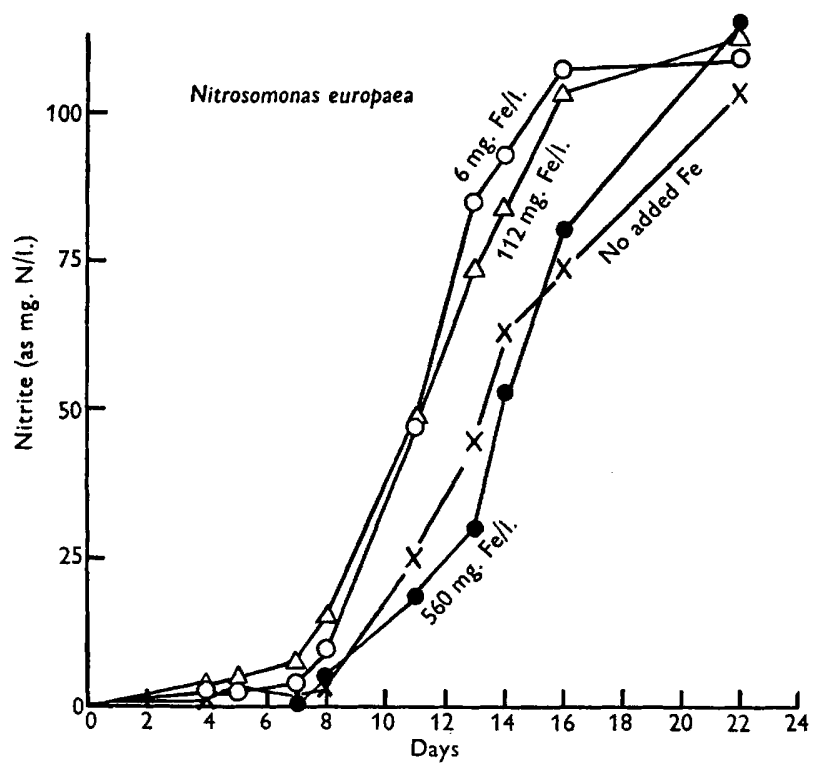

Fig. 4. Effect of large concentration of Fe on oxidation of ammonia to nitrite by Nitrosomonas europaea. $\times-\times$, control (no added Fe); $\mathrm{O}-\mathrm{O}, 6 \mathrm{mg}$. Fe/l.; $\triangle-\Delta$, $112 \mathrm{mg}$. Fe/1.; - $-560 \mathrm{mg}$. Fe/l.

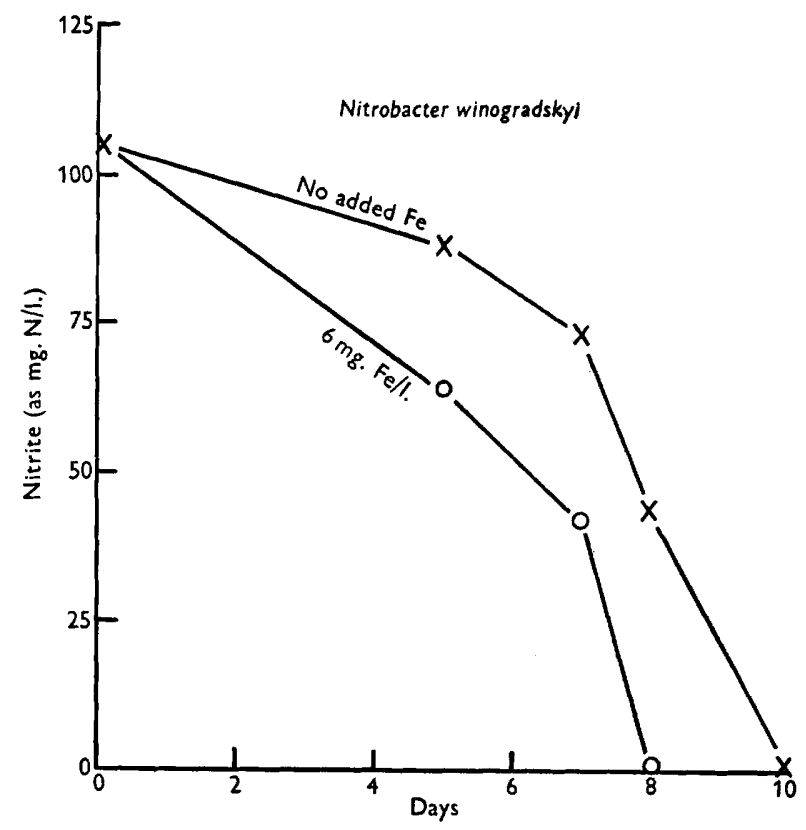

Fig. 5. Oxidation of nitrite to nitrate by a strain of Nitrobacter winogradskyi. $\times-\times$, control (no added $\mathrm{Fe}$ ); $\mathrm{O}-\mathrm{O}, 6 \mathrm{mg}$. Fe/l. (Average values from duplicate cultures.) 
The strain of Nitrobacter winogradskyi did not respond to such small amounts of iron as did the strains of Nitrosomonas. The results of experiments with less than $6 \mathrm{mg}$. Fe/l. are shown in Fig. 6, where the residual amounts of nitrite (i.e. not oxidized to nitrate) in the treated cultures are shown as percentage of the corresponding figure in the control culture, thus, a value of less than $100 \%$ indicates stimulation of oxidation. No stimulation was produced by $0 \cdot 1 \mathrm{mg}$. Fe/l.; stimulation was given by $0.3 \mathrm{mg}$. Fe/l. and the stimulating effect increased with concentration up to $6 \mathrm{mg}$. $\mathrm{Fe} / \mathrm{l}$.

The strain of Nitrobacter winogradskyi used was more sensitive than the Nitrosomonas strains to large doses of iron (Fig. 7).

\section{DISCUSSION}

The amounts of iron added, by different workers, to media used for growing nitrifying bacteria, have been very various; most early workers used Omeliansky's (1899) medium, which contains c. $80 \mathrm{mg}$. Fe/l. Jensen (1950) considered this iron concentration too high, and decreased it to $20 \mathrm{mg}$. Fe/l. in the medium he used for Nitrosomonas spp., the same concentration as used by Bömeke (1949). Most American workers, following Gibbs (1919), included 'a trace' of iron in their media. Kingma Boltjes (1935) and Hanks \& Weintraub (1936) used $2 \mathrm{mg}$. Fe/l. for Nitrosomonas spp. It is not suggested that all strains of nitrifiers have the same optimum requirements for iron, but it may well be that some of the trouble that has been reported in getting nitrifiers to grow has been due to unsuitable Fe concentrations in the media.

Bömeke (1949) found that not adding iron to his media had no effect on Nitrobacter spp.; Nitrosomonas sp. strain 44 (later, 1951, classified as $N$. oligocarbogenes) formed, in a month, $82 \%$ of the amount of nitrite formed when iron was supplied; but Nitrosomonas sp. strain 32, which he regarded as authentic $N$. europaea, did not form nitrite unless iron was added.

The present work shows that the absolute requirements for iron, of the strains investigated, are very small. Oxidation of ammonia and of nitrite went to completion in media purified with 8-hydroxyquinoline, and without added iron. But small amounts of iron stimulated oxidation by both species; the lowest concentration giving this effect was $0 \cdot 1 \mathrm{mg}$. Fe/l. for the strains of Nitrosomonas sp. and $\mathbf{0 . 3} \mathrm{mg}$. Fe/l. for the strain of Nitrobacter winogradskyi. The optimum amount of iron for the oxidations by all the strains appeared to be about $6 \mathrm{mg}$. Fe/l. which is unusually high for bacteria. Waring \& Werkman (1942b) reported that maximum growth of Aerobacter aerogenes, $A$. indologenes, Klebsiella pneumoniae and Bacterium coli was obtained with only 0.02$0.03 \mathrm{mg}$. Fe/l.; Pseudomonas aeruginosa (which has a complete cytochrome system) needed $0 \cdot 09-0 \cdot 10 \mathrm{mg}$. Fe/l. for maximum growth; Serratia marcescens needed $0.03 \mathrm{mg}$. Fe/l. for growth, and $0.3 \mathrm{mg}$. Fe/l. for maximum pigment production. Young, Begg \& Pentz (1944) found that Bact. coli needed 0.51.4 mg. Fe/1. for optimum growth, when enough magnesium was supplied. McNaught, Owen \& Smith (1950) found that the mixed bacteria of the cow's rumen needed 1-2 mg. Fe/l. for good growth.

The optimum value of $6 \mathrm{mg}$. Fe/l. for the nitrifiers here reported is of the 


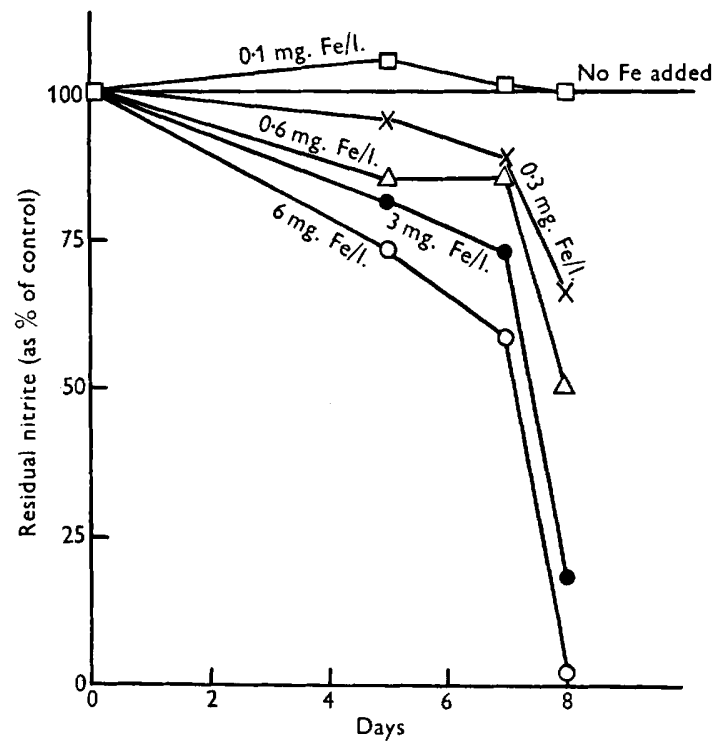

Fig. 6. Oxidation of nitrite to nitrate by a strain of Nitrobacter winogradskyi. Residual nitrite shown as percentage of that in the control with no added $\mathrm{Fe}$, at corresponding times. $\square-\square, 0.1 \mathrm{mg}$. Fe/l.; $x-x, 0.3 \mathrm{mg}$. Fe/l.; $\triangle-\Delta, 0.6 \mathrm{mg}$. Fe/l.; $3.0 \mathrm{mg}$. Fe/l.; $\mathrm{O}-\mathrm{O}, 6.0 \mathrm{mg}$. Fe/l. (Average of duplicates.) The nitrite content of the control cultures with no added Fe is shown as the solid horizontal line at $100 \%$.

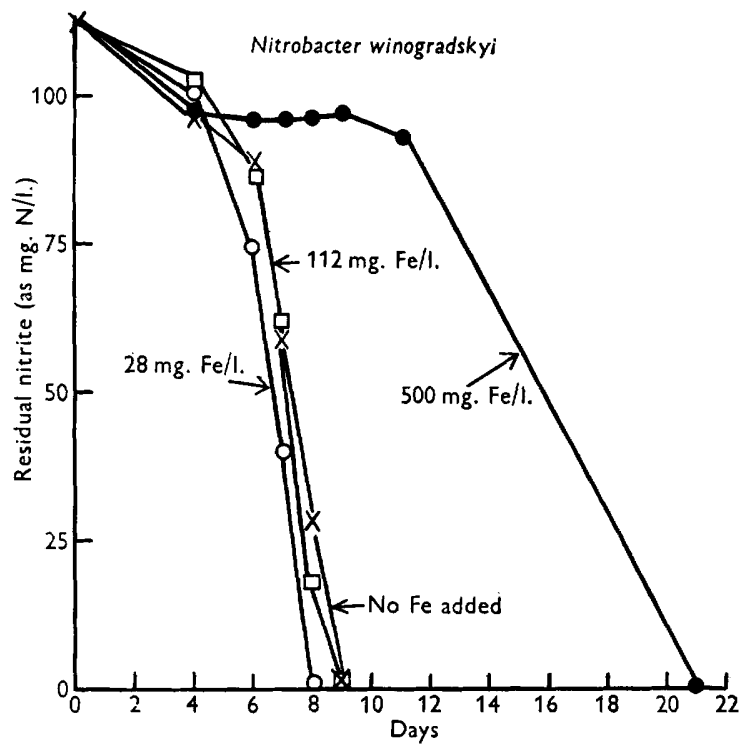

Fig. 7. Oxidation of nitrite to nitrate by a strain of Nitrobacter winogradskyi. $\times-\times$, control (no Fe added); $\bigcirc-0,28 \mathrm{mg}$. Fe/l.; $\square-\square, 112 \mathrm{mg}$. Fe/1.; -0, 560 mg. Fe/l. 
order found for the growth of Aspergillus spp. (Steinberg, 1919; Roberg, 1928). The nitrifiers appear also able to tolerate relatively large quantities of iron, up to $112 \mathrm{mg}$. Fe/l. Waring \& Werkman $(1942 b)$ reported some decrease in growth of the species of bacteria they examined in presence of as little as 3-4 mg. Fe/l. when the iron was supplied as an inorganic salt; iron supplied as citrate was tolerated at $100 \mathrm{mg}$. Fe/l. Iron at $0.01 \mathrm{M}$, reported by Meyerhof (1916) to inhibit respiration of the Nitrosomonas strains he examined, was found in the present work to delay oxidation by the Nitrosomonas strains slightly, and by the strain of Nitrobacter winogradskyi more severely.

I wish to thank Dr H. L. Jensen for sending cultures of his strain of Nitrosomonas europaea; Dr H. G. Thornton, F.R.S., for his encouragement; Miss E. McCall, Miss F. Zweig and Miss A. Roe for technical help.

\section{REFERENCES}

Bömeke, H. (1949). Über die Ernährungs- und Wachstumsfaktoren der Nitrifikationsbakterien. Arch. Mikrobiol. 14, 63.

BöмекE, H. (1951). Nitrosomonas oligocarbogenes, ein obligat autotrophes Nitritbakterium. Arch. Mikrobiol. 15, 414.

Gibss, W. M. (1919). The isolation and study of nitrifying bacteria. Soil Sci. 8, 42\%.

Hanks, J. H. \& Weintraub, R. L. (1936). The pure culture isolation of ammoniaoxidising bacteria. J. Bact. 32, 653 .

Jensen, H. L. (1950). En Stamme af Nitrosomonas europaea fra Stalgødning. Tidsskr. Planteavl, 54, 62.

Kingma BoltJes, T. Y. (1935). Untersuchungen über die nitrifizierenden Bakterien. Arch. Mikrobiol. 6, 79.

Lees, H. \& Meiklejohn, J. (1948). Trace elements and nitrification. Nature, Lond. 161, 398.

Lees, H. \& Quastel, J. H. (1946). Biochemistry of nitrification in soil. Biochem. J. $40,803$.

MeNaught, M. L., Owen, E. C. \& Sмiтh, J. A. B. (1950). The utilization of nonprotein nitrogen in the bovine rumen. 6. The effect of metals on the activity of the rumen bacteria. Biochem. J. 46, 36.

Meiklejohn, J. (1950). The isolation of Nitrosomonas europaea in pure culture. J. gen. Microbiol. 4, 185.

Meyerhof, O. (1916). Die Atmung des Nitritbildners und ihre Beeinflussung durch chemische Substanzen. Pflüg. Arch. ges. Physiol. 166, 240.

Omeliansky, V. (1899). Über die Isolierung der Nitrifikationsmikroben aus dem Erdboden. Z Zbl. Bakt. (2 Abt.), 5, 537.

Roberg, M. (1928). Über die Wirkung von Eisen-, Zink-, und Kupfersalzen auf Aspergillen. Zbl. Bakt. (2 Abt.), 74, 333.

Steinberg, R. A. (1919). A study of some factors in the chemical stimulation of the growth of Aspergillus niger. Amer. J. Bot. 6, 330.

Waring, W. S. \& Werkman, C. H. (1942a). Growth of bacteria in an iron-free medium. Arch. Biochem. 1, 303.

Waring, W. S. \& Werkman, C. H. (1942b). Iron requirements of heterotrophic bacteria. Arch. Biochem. 1, 425.

Winogradsky, S. \& Omeliansky, V. (1899). Über den Einfluss der organischen Substanzen auf die Arbeit der nitrifizierenden Mikroben. Zbl. Bakt. (2 Abt.), $5,329,377,429$.

Young, E. G., BegG, R. W. \& Pentz, E. I. (1944). The inorganic nutrient requirements of Escherichia coli. Arch. Biochem. 5, 121.

(Received 14 June 1952)

G M VIII I 